\title{
Dropping habilitation would aid progress in Poland
}

\section{Standards are high in many disciplines, but changes are still needed in career structure.}

Sir - I enjoyed your Editorial "Eastern promise" (Nature 426, 369; 2003), but I disagree with Cezary Wójcik's response, "Eastern Europe; progress stifled by the old guard" (Nature 427, 196; 2004). If the system in Poland is - as described by the author - "hierarchical, immobile, hermetic and gerontocractic", how has it managed to educate postdocs and students who are successful in the best laboratories in the world? The answer is simple: the picture is not as homogeneous as Wójcik suggests. At almost every university or institute of the Polish Academy of Sciences there are scientists who have chosen to remain in Poland, even though they could find positions in the United States or Western Europe.

Disciplines do vary, but in physics, mathematics, biology and chemistry at least, the standards are much higher than Wójcik describes. I am a professor of molecular biology and I probably belong to the "scientific establishment" Wójcik derides. Only three of some 80 publications that I have authored appeared in Polish journals, and I became a professor in Poland after my Polish team published a paper in Cell and several others in EMBO Journal and Proceedings of the National Academy of Sciences.

I also disagree with the view that "[m] ost research money is distributed by arbitrary administrative decisions, not as peer-reviewed grants". More than 10 years ago the State Committee for Scientific Research, composed entirely of elected members, introduced a grant system, based on a peer-review procedure that mirrors the US National Science Foundation. All grant applications in the life sciences have to be submitted in English and we ask reviewers from abroad to rank them.

Four years ago we introduced a new system for distributing science funding based only on the quality of the scientific work performed in Polish institutions (see www.kbn.gov.pl). We initiated special programmes on genomics, proteomics, bioinformatics and biodiversity, and we ask scientists from Germany, France, Sweden and the United Kingdom to validate them.

We are collaborating closely with the European Molecular Biology Organization and the Howard Hughes Medical Institute for additional support of young Polish investigators, who are selected by these distinguished organizations. We are opening new Max Planck-Polish Academy of Sciences laboratories for young scientists working in molecular biology. Similarly, young scientists working at the International Institute of Molecular and Cell Biology in Warsaw are recruited according to international standards (Nature 421, 471-472; 2003). Independent positions are awarded on scientific criteria alone, and neither a habilitation nor the title of professor is required.

Certainly, change is happening too slowly, especially for young people. Therefore, I am convinced that upon entering the European Union, we have to forget about habilitations and introduce international competition for all independent positions, from assistant to full professor.

Maciej Zylicz

International Institute of Molecular and Cell Biology, 4 Ks. Trojdena Street, 02-109 Warsaw, Poland and Chairman of the Biology, Earth Sciences and Environmental Protection Unit, State Committee for Scientific Research, 113 Wspolna Street, 00-529 Warsaw 53, Poland

\section{Polish journals have an international impact}

Sir-Cezary Wójcik, in Correspondence ("Eastern Europe; progress stifled the old guard" Nature 427, 196; 2004), expresses a view of Polish science that is true only to some extent. As young Polish scientists, working both in Poland and abroad, we wish to offer a counterbalancing viewpoint.

First, we do not deny that in some cases a scientific career may be based on "personal or political connections". But to suggest this applies to the whole of Polish science, as Wójcik does, is an exaggerated generalization. The habilitation is not a mysterious qualification unrelated to any real scientific achievements, but an academic grade having its equivalents in other Western European countries although in Germany it is no longer required to become a full professor.

Second, the medical sciences require particularly expensive materials and methods, and should not be considered as representative of all scientific disciplines, but rather as an exception.

Similarly, Polish medical journals may not always be internationally recognized, but other disciplines fare better. For example, Acta Palaeontologica Polonica has an impact factor between 0.67 and 1.0 (data for 2001-02), which places it between tenth and fifteenth in the world rankings of the 29 indexed scientific journals in this field, and Acta Astronomica (impact factor 3.2 in 2002) ranks ninth in astronomy.

Adam T. Halamski*, Dorota Religa $\dagger$

${ }^{*}$ Institute of Paleobiology, Polish Academy of Sciences, Twarda 51/55, 00-818 Warszaw, Poland and Université Claude-Bernard-Lyon 1, UFR des Sciences de la Terre, UMR PEPS, 43 boulevard du 11 novembre, 69622 Villeurbanne cedex, France $\dagger$ Karolinska Institutet, Neurotec, Novum, plan 4, 14186 Stockholm, Sweden and Medical Research Centre, Polish Academy of Sciences, Pawinskiego 5, 02-106 Warsaw, Poland

\section{Learning humility from a Nobel prizewinner}

Sir — The Dutch biologist Niko Tinbergen - whose biography, Niko's Nature by Hans Kruuk, is reviewed by John Krebs (Nature 427, 293-294; 2004) - may help us to understand one of the problems with German science outlined in the Editorial in the same issue (Nature 427, 271; 2004).

Tinbergen had an extraordinary characteristic that accounts, I believe, for his ability to develop intellectually throughout his life, and stimulate his students and colleagues to do so too. It was his humility. At the weekly seminars that he held in his home for his fellow ethologists and others, I observed that he never hesitated to display his initial incomprehension of a new idea; he was determined to understand. It was an object lesson to his group.

This characteristic was unfortunately not shared by many of his peers. At the European conferences that he organized with his fellow Nobel prizewinners, it was striking how many German professors used their authority to determine what their juniors contributed. This must have been stultifying for both.

Although scientific hierarchies have become less rigid in Germany, Chancellor Gerhard Schröder would do well to encourage more egalitarian intellectual innovation as he develops his plans for several new 'élite’ German universities. John Godfrey

41 Lawford Road, London NW5 2LG, UK

\section{correspondence}

Contributions to Correspondence may be submitted to corres@nature.com. They should be no longer than 500 words, and ideally shorter. Published contributions are edited. 